\title{
Public-Supply Water Use in Kansas, 1990-2012
}

\section{Abstract}

This fact sheet describes water-use data collection and quantities of surface water and groundwater diverted for public supply in Kansas for the years 1990 through 2012. Data used in this fact sheet are from the Kansas Department of Agriculture's Division of Water Resources and the Kansas Water Office. Water used for public supply represents about 10 percent of all reported water withdrawals in Kansas. Between 1990 and 2012, annual withdrawals for public supply ranged from a low of 121 billion gallons in 1993 to a high of 159 billion gallons in 2012. Differences in annual withdrawals were associated primarily with climatic fluctuations. Six suppliers distributed about one-half of the total water withdrawn for public supply, and nearly threequarters of the surface water. Surface water represented between 52 and 61 percent of total annual withdrawals for public supply. The proportion of surface water obtained through contracts from Federal reservoirs increased from less than 5 percent in the 1990s to 8 percent in 2011 and 2012. More than 99 percent of the reported water withdrawn for public supply in Kansas in 2012 was metered, which was an increase from 92 percent in 1990. State population increased steadily from 2.5 million people in 1990 to 2.9 million in 2012. Recent estimates indicate that about 95 percent of the total population was served by public water supply; the remainder obtained water from other sources such as private wells. Average per capita water use as calculated for State conservation planning purposes varied by region of the State. The smallest regional average water use for the years 1990-2012 was 98 gallons per person per day in easternmost Kansas, and the largest regional average water use was 274 gallons per person per day in westernmost Kansas.

\section{Introduction}

Water-use data are essential to management of water resources in Kansas. Water diverted for public supply represents about 10 percent of total reported water use in Kansas. All diversions of water for public supply on non-Federal lands within the State are regulated by the Kansas Department of Agriculture's Division of Water Resources (DWR) or the Kansas Water Office (KWO). This fact sheet describes quantities of surface water and groundwater diverted for public supply for the years 1990 through 2012, using data collected by these two agencies.

Locations of surface-water and groundwater points of diversion for public supply in 2012 are shown in figure 1. Most public-supply diversions in Kansas are regulated under municipal water rights administered by the DWR. The Kansas Water Appropriation Act of 1945 requires permits to appropriate water for any uses other than domestic (Kansas Department of Agriculture, 2014). In Kansas, municipal use (equivalent to public supply) is defined as the various uses made of water delivered through a common distribution system operated by a municipality, rural water district, public wholesale water district, correctional facility, or any person or entity serving 10 or more residences or mobile homes. Other public-supply diversions in Kansas are administered through the Water Marketing Contract Program established in 1974 by the State Water Plan Storage Act, which authorized the KWO to contract with municipal and industrial water purchasers for sale of water from State-owned storage in Federal reservoirs (Kansas Water Office, 2014). Water diverted under water rights and marketing contracts includes amounts subsequently sold or distributed to public suppliers without water rights, and so represents the total amount of water eventually used for public supply.

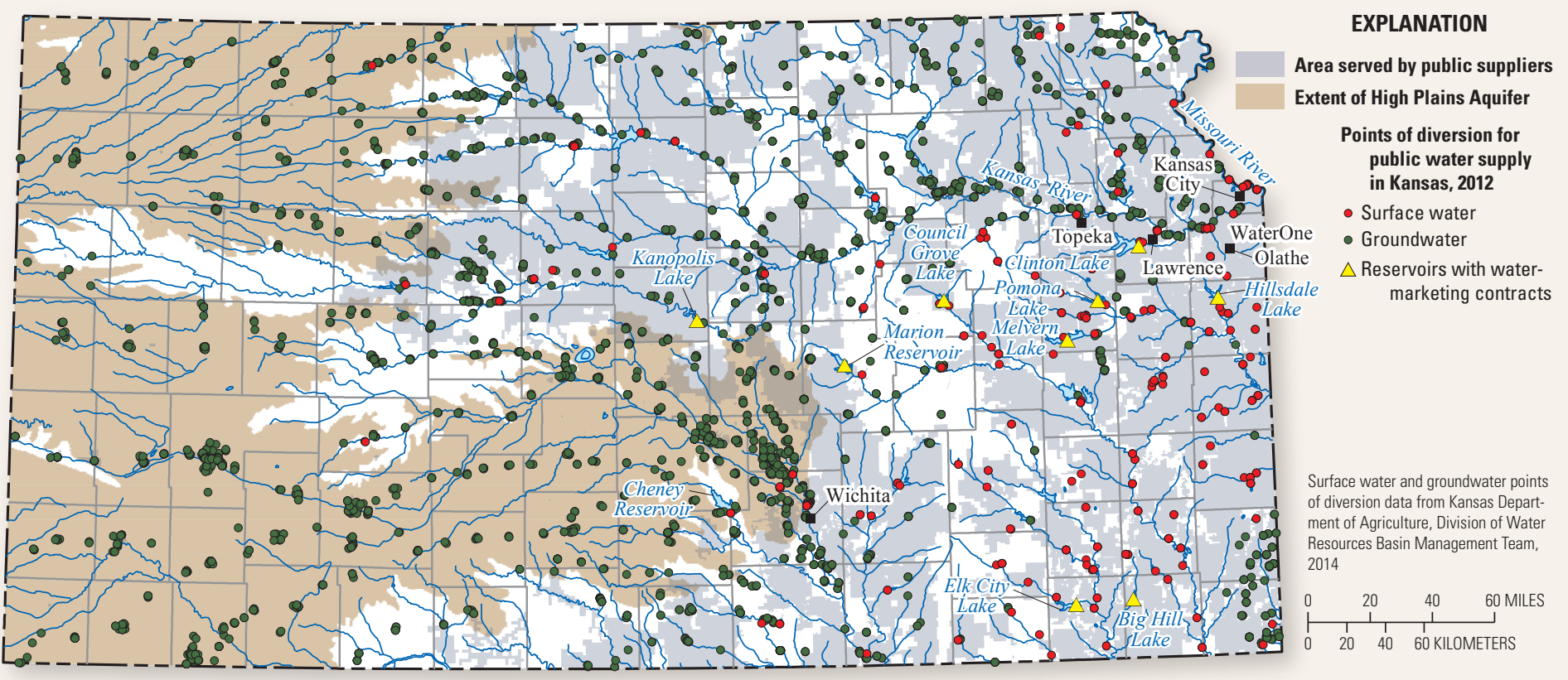

Figure 1. Location of public water supply points of diversion in 2012. 
Surface water was diverted from streams, springs, and lakes representing 170 active DWR water rights; and from 9 federal reservoirs used for municipal supply through the KWO Water Marketing Program. Most of these surface-water diversions are in the eastern one-half of Kansas. Groundwater was diverted under water rights from about 2,600 wells, located primarily along streams and in areas underlain by the High Plains Aquifer.

\section{Data Collection}

Owners of water rights are required to report their water use annually to the DWR, and compliance has been excellent since penalties for not reporting were enacted in 1988 (Kansas Department of Agriculture, 2014, K.S.A. 82a-732). Data submitted on the water-use reports are stored in the DWR's Water Rights Information System database (WRIS). The KWO maintains monthly records of water purchased through its Water Marketing Program. Marketing purchases by water suppliers are included on the DWR annual reports, but the withdrawals must be accounted for separately because they are stored in WRIS as purchases rather than diversions. Most of the reported water withdrawn for public supply in Kansas is metered rather than calculated using hours and pump rates. In 1990, about 92 percent of all reported public-supply use was metered; in 2012, more than 99 percent was metered.

Annual municipal water-use reports were expanded in 1987. In addition to reporting amounts of water diverted under water rights, water suppliers were asked to report wholesale purchases and sales; water sold for industrial and livestock uses; water sold to residential and commercial customers; and (beginning in 1992) other metered water used for public services such as park irrigation, public pools, and water treatment. The difference between water diverted and/or purchased and all metered sales and other uses is considered unaccounted for water. The annual water-use reports also request information on the retail population served and numbers of service connections.

Of approximately 700 annual municipal water-use reports filed each year by entities with DWR water rights (known as primary water-use reports), about 600 are from water suppliers that serve retail customers year-round (such as cities, rural water districts, mobile home parks, and housing subdivisions) or are for wholesale water districts. The other reports are filed by noncommunity water systems such as campgrounds, churches, hospitals, and schools. The amount of water reported annually by these noncommunity water systems represents only about 0.1 percent of all reported diversions for public supply in Kansas.

Beginning in 2000, the DWR began to request annual wateruse reports from approximately 250 water suppliers without DWR water rights, including systems that purchase water from other suppliers and wholesale districts that divert water under KWO marketing contracts. These are known as nonprimary water systems, and are not subject to penalties for nonreporting. Nearly 80 percent of the requested nonprimary reports are returned each year to the DWR. Obtaining similar reports from both primary and nonprimary water systems has improved the information available on water systems, their sources of supply, and populations served. Numbers of primary and nonprimary water suppliers fluctuate as water suppliers acquire or abandon water rights, new water-supply systems are established, or existing ones merge with others. In 2012, more than one-half of Kansas water suppliers relied solely on their own sources of supply, more than one-third purchased all their water from other suppliers or wholesale districts, and about 10 percent used combinations of their own supplies and purchased water.

\section{Public Water Supply Withdrawals}

Total quantities of water withdrawn for public supply by source from 1990 to 2012 are shown in figure 2. Total withdrawals ranged from a low of 121 billion gallons in 1993 to a high of 159 billion gallons in 2012. Surface-water withdrawals, including those with DWR water rights and those with KWO water marketing contracts, ranged from a low of 63 billion gallons in 1993 to a high of 95 billion gallons in 2012. Surface water represented between 52 percent and 61 percent of total annual withdrawals for public supply. The quantities of water obtained annually from Federal reservoirs through KWO contracts increased from about 3 billion gallons per year in 1990 (less than 5 percent of all surface-water withdrawals) to more than 7 billion gallons per year in 2011 and 2012 (8 percent of all surface-water withdrawals). Groundwater withdrawals varied less with time than surface-water withdrawals, ranging from a low of 53 billion gallons in 2009 to a high of 65 billion gallons in 1991 .

About 52 percent of the total water withdrawn in 2012, and 73 percent of the total surface water, was treated and distributed by six water suppliers located in the most populous areas of the State (fig. 1). In order of magnitude of withdrawals, these suppliers and their primary sources of water are the following:

1. WaterOne (Water District 1 of Johnson County), Kansas and Missouri Rivers

2. Wichita, Cheney Reservoir and wells

3. Kansas City (Board of Public Utilities), Missouri River collector wells

4. Topeka, Kansas River

5. Olathe, Kansas River collector wells

6. Lawrence, Clinton Lake and Kansas River.

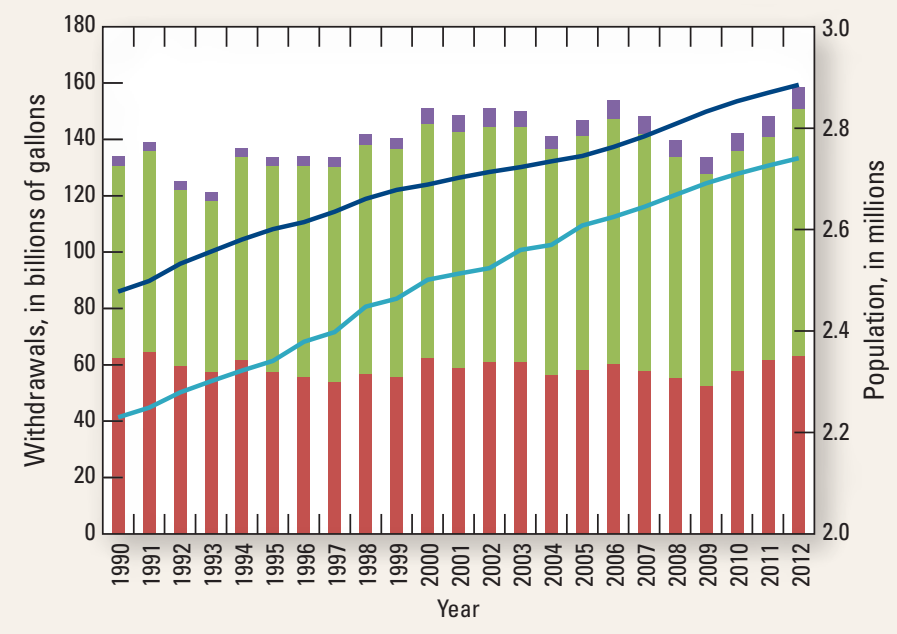

EXPLANATION

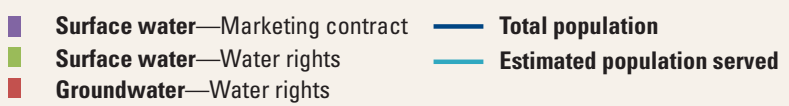

Figure 2. Annual public-supply withdrawals by source and population in Kansas, 1990-2012. 
Kansas population trends also are shown in figure 2. The total population of Kansas grew steadily from nearly 2.5 million in 1990 to almost 2.9 million in 2012. Estimates made by USGS every 5 years indicate that about 90 percent of that population was served by public supply in 1990 and 1995, 93 percent in 2000, and 95 percent in 2005 and 2010 (Solley and others, 1993, 1998; Hutson and others, 2004; Kenny and others, 2009; and Maupin and others, 2014).

The largest amounts of water typically are withdrawn for public supply during the driest years because of increases in outdoor watering. From 1990 through 2012, the largest withdrawals occurred during years when the State average annual precipitation was less than 30 inches. The largest amounts of water were reported for public supply in 2012, when average annual precipitation for Kansas was less than 20 inches. Publicsupply withdrawals were smallest in 1993, when average annual precipitation was nearly 40 inches. The relation between total withdrawals and average annual precipitation for the State is shown in figure 3.

\section{Per Capita Water Use}

Water use is often described in terms of daily per capita use, commonly known as gallons per person per day (gpcd). Using data from the annual water-use reporting program, derivative statistics on per capita water use by Kansas public water suppliers have been prepared annually since 1988 (Kansas Department of Agriculture, 1988-2014). Per capita data have been valuable to the DWR in administering water rights and to the KWO for forecasting and water conservation planning. Per capita use for each water supplier with a retail population served is based on amounts of water reported for residential and commercial sales, metered free uses, and unaccounted for water. Including all unsold water in the calculation results in per capita values that reflect the particular needs of individual systems (such as water treatment and public services) and system losses. Excluding amounts of water sold for industrial and livestock uses, which vary from none to substantial amounts among water suppliers, allows more equitable comparison of per capita use.

Average per capita use is largest in western Kansas and smallest in eastern Kansas because of more arid conditions in the west, and is typically lower for small towns than large cities (Kenny, 2000; Kansas Department of Agriculture, 1988-2014). Recognition of geographic differences in per capita water use resulted in grouping of water suppliers by eight regions within the State so that an individual supplier's per capita use could be compared to averages of systems

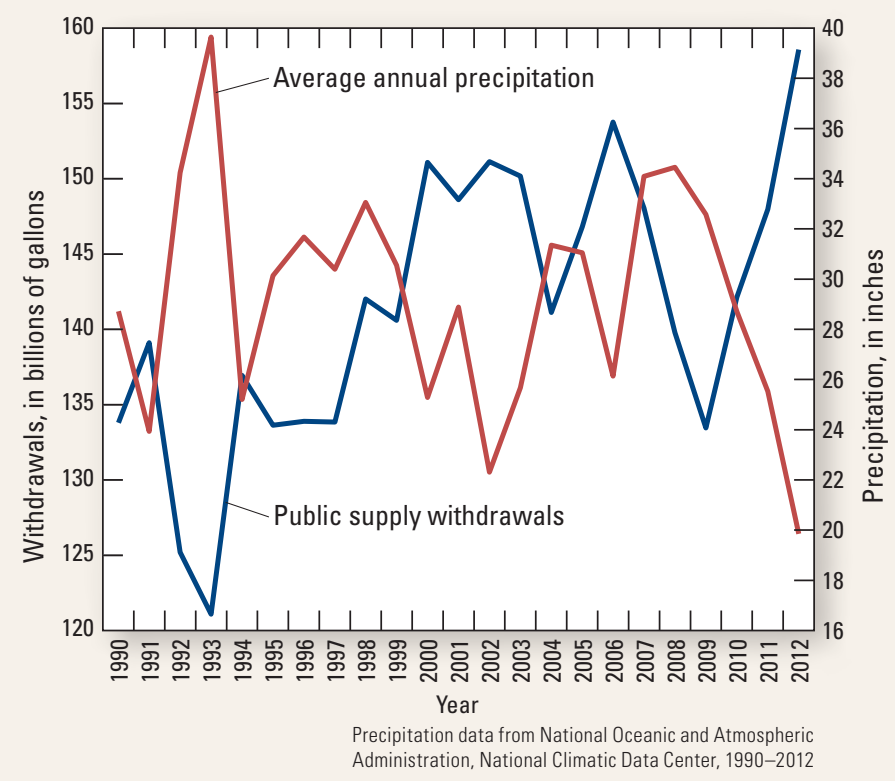

Figure 3. Annual public-supply withdrawals and average annual precipitation, Kansas, 1990-2012.

in similar geographic areas. As part of State efforts to evaluate progress in conservation efforts, the regional averages were calculated as the average of individual per capita uses within each regional group.

The eight regions used for analysis of per capita water use are shown in figure 4 along with the number of water suppliers used to compute the 2012 average per capita use in each region. Regions 1 through 5 are narrow in width because per capita use increases greatly from central Kansas to the western border. Regions 6 through 8 in central and eastern Kansas are wider because there is generally less variation in usage. Numbers of water systems increased after the year 2000 when additional reports were collected from nonprimary water suppliers,

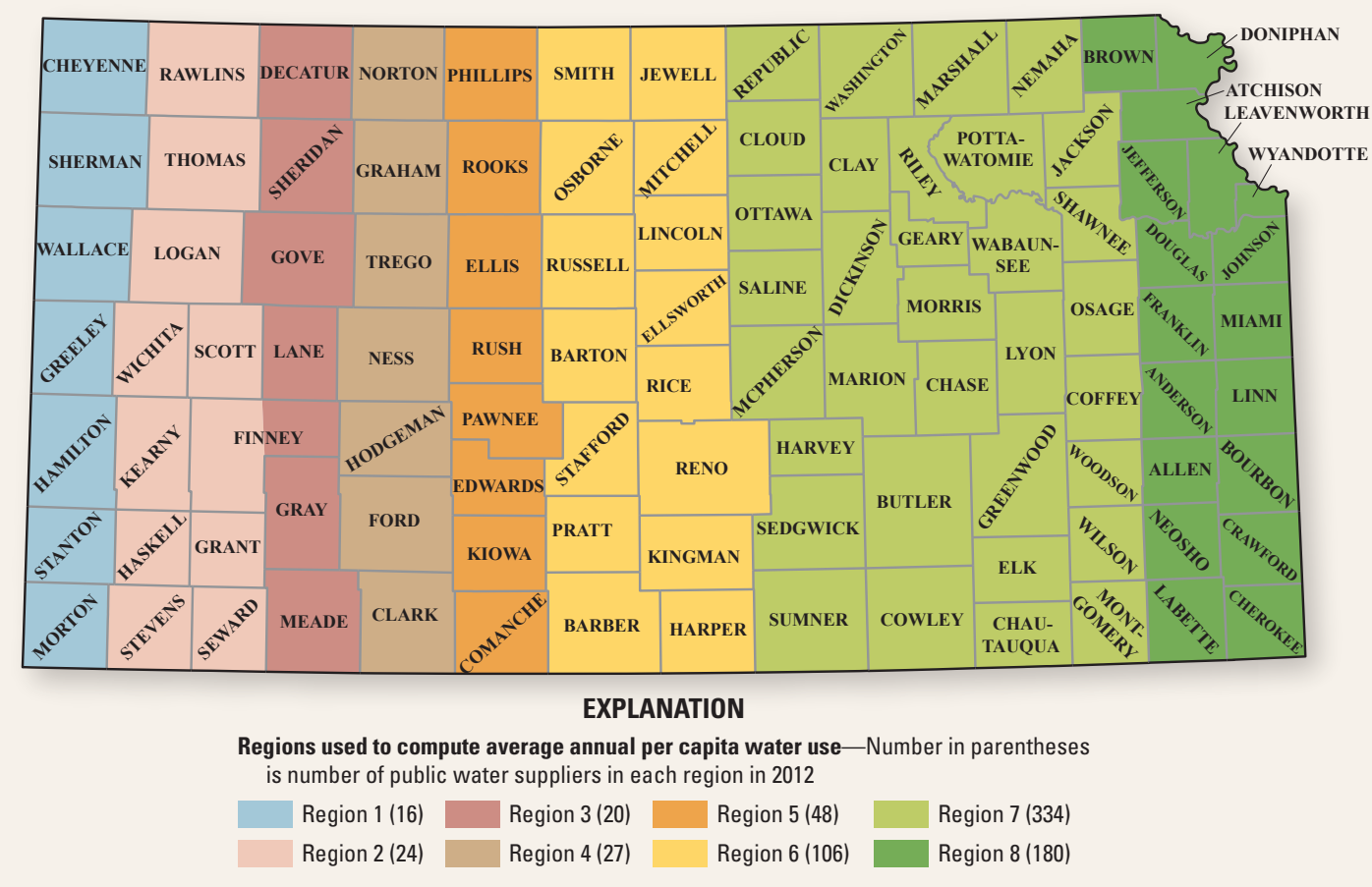

Figure 4. Regions used for analysis of per capita water use in Kansas, and number of public water suppliers used to compute regional average in each region for 2012. 
which are most commonly small (population less than 500) and medium-sized (population from 500-9,999) systems in regions 7 and 8. Mobile home parks were not included in the regional per capita averages for any years.

Regional average per capita uses from 1990 to 2012 for eight regions of the State, and the State average, are shown in figure 5. The largest per capita averages and the greatest variability from year to year have occurred in regions 1 through 5 , because of the more arid conditions in those regions and the small numbers of water suppliers in each. Smaller per capita averages and less variability occurred in regions 7 and 8 , because there is typically greater precipitation and larger numbers of water suppliers. The largest average uses were in region 1 and ranged from $228 \mathrm{gpcd}$ in 2009 to 321 gpcd in 2002; the region 1 average was 274 gpcd for the period 1990-2012. The smallest average uses were in region 8 and ranged from 87 gpcd in 2009 to 108 gped in 1991; the region 8 average for 1990-2012 was 98 gpcd. The largest per capita averages in nearly every region were during 1990 and 1991, which were the last 2 years of a severe drought that began in 1988. Nearly all regional per capita averages also showed sharp increases in 1994, 2000, 2002, 2006, and 2010-12. Average use was smallest in nearly all regions in 2009 , which was the third year of above-normal precipitation in central and eastern climatic divisions of Kansas (National Oceanic and Atmospheric Administration, 1988-2012).

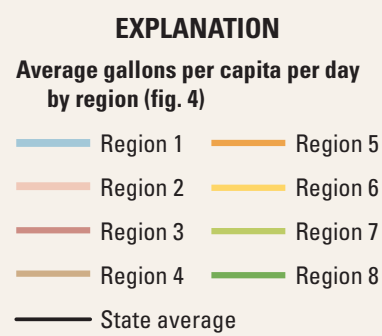

Figure 5. Regional and State gallons per capita per day averages, Kansas, 1990-2012.

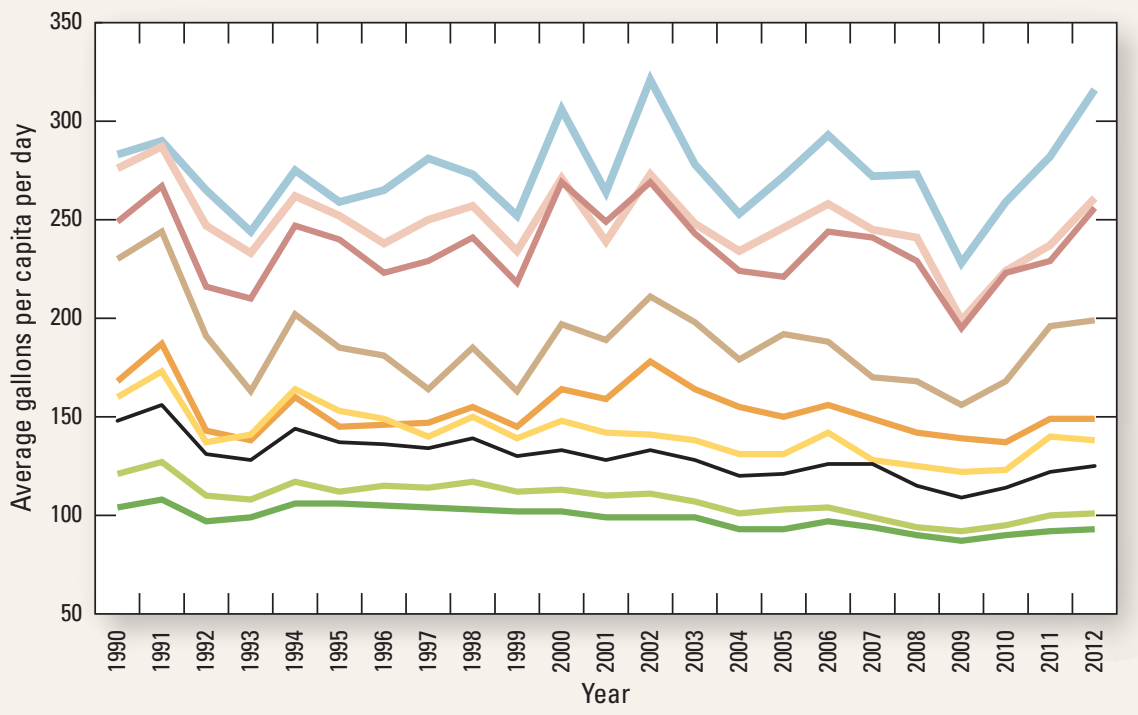

\section{Acknowledgments}

This study was made possible, in part, by support from the Kansas Department of Agriculture, Division of Water Resources, and the Kansas State Water Plan Fund.

\section{References Cited}

Hutson, S.S., Barber, N.L., Kenny, J.F., Linsey, K.S., Lumia, D.S., and Maupin, M.A., 2004, Estimated use of water in the United States in 2000: U.S. Geological Survey Circular 1268, 46 p.

Kansas Department of Agriculture, Division of Water Resources, 1988-2014, Kansas municipal water use: Topeka, Kansas, [published annually since 1988, pagination and authorship varies, available on request from Kansas Department of Agriculture].

Kansas Department of Agriculture, 2014, Kansas water appropriation act: Kansas Department of Agriculture, 29 p., accessed November 14, 2014, at http://agriculture.ks.gov/docs/defaultsource/statues-water/kswaterappropriationact82a_701. pdf? sfursn $=4$.

Kansas Water Office, 2014, Projects and Programs: Kansas Water Office Web page, accessed November 6, 2014, at http://www.kwo. org/projects_programs/Projects_Programs.htm.

Kenny, J.F., 2000, Public water-supply use in Kansas, 1987-97: U.S. Geological Survey Fact Sheet 187-99, 4 p.

Kenny, J.F., Barber, N.L., Hutson, S.S., Linsey, K.S., Lovelace, J.K., and Maupin, M.A., 2009, Estimated use of water in the United States in 2005: U.S. Geological Survey Circular 1344, 52 p.
Maupin, M.A., Kenny, J.F., Hutson, S.S., Lovelace, J.K., Barber, N.L., and Linsey, K.S., 2014, Estimated use of water in the United States in 2010: U.S. Geological Survey Circular 1405, $56 \mathrm{p}$.

National Oceanic and Atmospheric Administration, 1988-2012, Climatologic data, annual summary, Kansas: Asheville, North Carolina, National Climatic Data Center, v. 102-126 [published annually].

Solley, W.B., Pierce, R.R., and Perlman, H.A., 1993, Estimated use of water in the United States in 1990: U.S. Geological Survey Circular 1081, 76 p.

Solley, W.B., Pierce, R.R., and Perlman, H.A., 1998, Estimated use of water in the United States in 1995: U.S. Geological Survey Circular 1200, 71 p.

\section{By Joan F. Kenny}

For additional information concerning this publication, contact:

Director, USGS Kansas Water Science Center 4821 Quail Crest Place, Lawrence, KS 66049 (785) 842-9909

\section{Or visit the Kansas Water Science Center} Web site at:

http://ks.water.usgs.gov 